\title{
Occupational health education in the United Kingdom workplace: looking backwards and going forwards? The Industrial Health Education Society
} at work 1922-40

\author{
A Watterson
}

\begin{abstract}
Education on occupational medicine is a neglected area in the United Kingdom in terms of resources and staffing. Education on occupational health and safety is even more neglected and education in the workplace on occupational health is most neglected of all. 1944 saw the demise of the Industrial Health Education Society. This society had been established with the explicit aims of educating and informing ordinary shopfloor workers about occupational hazards and how to deal with them. The emphasis was almost exclusively on occupational health and not occupational safety. In this and indeed in several other respects the society was unique. The society functioned effectively between 1924 and 1940. Large numbers of doctors were recruited to give their time and services free to the IHES by talking to workers on occupational health topics. In this manner the society succeeded in attracting many thousands of workers to its meetings and worked without openly alienating employers, trade unions, the government, or the medical profession-a remarkable feat of diplomacy. The strengths and weaknesses of the society are charted as are the themes and issues still relevant in the 1990s. Progress in the 1980 s is assessed against the background of the IHES achievements.
\end{abstract}

Today there is both interest in and justified concern about the state of occupational medical education in United Kingdom medical circles. There are worries about the funding of occupational medicine departments in universities, occupational health and safety departments in universities and polytechnics, and the

Workplace Health, Safety and Environment Research Group, Department of Adult Education, University of Southampton, Southampton SO9 5NH A Watterson undergraduate training of physicians in occupational. health. ${ }^{1-3}$ Professional training in occupational health and safety has generated rather less interest. ${ }^{4}$ oे

The comparatively neglected state of occupationalo health education in the workplace has provoked little $\stackrel{ }{-}$ interest despite the importance of the subject in $ᄃ$ determining the success of the work of health and safety professionals. ${ }^{5-7}$ The effects of the training ${ }_{-}$ provisions in the 1974 Health and Safety at Work Act $\underset{\bigotimes}{\oplus}$ and various regulations (construction, abrasive? wheels, woodworking, pesticides) have not yet been properly investigated. The forthcoming Control of Substances Hazardous to Health Regulations also have important training implications. Yet in 1990 we know surprisingly little about the extent or indeed $\mathbb{\Phi}$ the effectiveness of the occupational health education $\overrightarrow{\vec{F}}$ work there has been for employees.

There is therefore some value in looking back to $\frac{3}{5}$ find out what was happening in occupational health education for workers in order to explain the origins of current developments and to help us assess those $\mathbb{D}$ developments. We should ensure that we do not? repeat the mistakes of the past-the punishment for 3 all those who ignore history.

In the $1980 \mathrm{~s}$, against a somewhat different econ- $\frac{0}{3}$ omic and political background to the $1920 \mathrm{~s}$ and 1930 s, the philosophy of self help and voluntarism? which has never completely vanished from the $\frac{7}{0}$ occupational health field re-emerged with a vengeance amid discussions of deregulation. Attempts to $N$ reduce the state provision of information, education, and enforcement of laws on occupational hazards $\mathrm{N}$ gained ground rapidly in the 1970 s. Some would $\omega$ argue that the flood of expensive publications from? the Health and Safety Commission (HSC) only lapse at the feet of many managers and fails to reach large numbers of shopfloor workers who cannot afford tobuy them. State provision of health and safety information or indeed enforcement has also been $\frac{\vec{D}}{\mathrm{D}}$ minimal in several sectors of our economy. Small businesses and small farms are rarely inspected and $\stackrel{\mathbb{Q}}{2}$ many owners will know little about the legislative and technical requirements necessary to protect theiro workforces. 
Information disclosure in an appropriate setting for workers, was the cornerstone of the Industrial Health Education Society (IHES) programme. Sir Thomas Oliver's belief that "workpeople employed in trades regarded as dangerous ought to be informed by an official of the factory of the risks they were running" stood at the centre of the IHES approach as it did in the work of Sir Thomas Legge ${ }^{9}$ who was also associated with the IHES. How far and how well these IHES objectives have been met by 1990 is something for all those in occupational health to consider.

\section{Setting the Scene}

The IHES and its forerunner functioned in Scotland, England, and Wales between 1922 and 1940 (although the society was not formally wound up until 1944). ${ }^{10}$

The 1920s and 1930s witnessed both considerable industrial discontent with great class conflict and also a range of government and employer initiatives, schemes, and policies. Some government and employer policies were designed to reduce conflict in the workplace and ensure continuous and efficient production for capital, basically through many consultation and conciliation programmes. Several of these policies were rooted in the late nineteenth and early twentieth centuries. Many employers, however, simply ignored the health and safety needs of their workers and continued with traditional management policies that did not recognise either workers' rights or workers' organisations.

The state played a growing part in both factory inspection and the development of voluntary health and safety and industrial relations schemes in the workplace. 1937 saw the passage of the consolidating Factories Act that added seven million people to the five and a half million already protected by previous factory legislation. In 1919 there were 169 factory inspectors in the United Kingdom: in 1938 there were 307. Little, however, was done either through government inspection or voluntary health and safety initiatives to improve conditions in non-factory and workshop workplaces. Information and education for shopfloor workers on health and safety was extremely limited.

Voluntary safety committees established in some factories after 1918, and hailed as the way forward on health and safety without state intervention, soon became stagnant in the mid 1920s. ${ }^{11}$ A plethora of societies, voluntary organisations, and research institutions appeared or developed in their place after 1918 to promote, among other things, voluntarism, victim blaming, and careless worker theories in the health and safety field. This work was allied to efforts to increase industrial harmony, reduce industrial discontent, and improve efficiency and productivity.
The organisations included the Welfare Workers Association (1913), Safety First Movement (1917), Industrial Fatigue Research Board (1918), Industrial Welfare Society (1918), National Institute of Industrial Psychology (1921), and Industrial Health Research Board (1928).

\section{Origins and work of IHES}

The society began in Scotland as the Industrial Health Education Council in 1922. It was founded by James Mackenzie, a printer who trained for missionary work and then became general secretary of the YMCA Scottish Council. The council reconstituted itself as the IHES in 1924 and in 1927 left its Glasgow offices and moved to London where it was based at the British Medical Association's offices in Tavistock Square. The IHES aims included:

(a) "the provision of lectures, information, and advice to industrial workers and others on occupational sicknesses, diseases, personal hygiene, general health, and accident prevention;

(b) to acquire and accumulate knowledge and information on occupational diseases etc;

(c) to encourage research on preventing and mitigating occupational diseases etc;

(d) to distribute literature and hold talks and lectures on the subject;

(e) to cooperate with medical and scientific bodies and with employers and workers on the subject" (Memorandum and Articles of Association of the IHES under the Companies Act July 1929).

Mackenzie was quite clear in 1927 that the aim of the IHES was not to hold public meetings but "to get workers together in groups to deal with the specific sickness and disease which afflicted them in their occupations." Prevention and not cure was the key objective for the IHES.

The IHES operated with an executive council of public figures, doctors, and lay activists together with TUC and trade union officials. Five area councils were established for the north of England, Scotland, the Midlands, west of England and Wales, and London. Scotland had a good deal of financial autonomy and merited its own full time organiser. Mackenzie, as general secretary, was the only paid full time national officer.

The philosophy of the IHES varied both in time and location but was rooted in safe worker theories. Initially, IHES discouraged employers from sitting on its councils so that workers would regard the society as "above suspicion." Indeed the editor of the Lancet had been moved to observe that it was vital that workers knew that employers were not behind the IHES lecturers because such suspicions had had "a malign influence" on worker confidence. (In the United States at this time workers did not trust the fashionable concepts of scientific management being peddled and so did not trust their employers to 
protect their health and safety.) The Editor also recognised that the IHES was such a valuable organisation exactly because the workers themselves invited the doctors to their clubs and canteens to talk about those subjects chosen by the workforce. The doctors were subject to rigorous questions and answers sessions ${ }^{12}$ : an unusually early model of medical accountability. By the late 1920 s, however, major and unsuccessful efforts were under way in the IHES to obtain financial and organisational support for the IHES work from employers.

IHES avowed that it would never answer questions about the state of factories and workshops because such matters were the concern of government factory inspectors despite being important factors in industrial health.

The society was also expected not to answer questions "on any political, industrial or social subjects. There is controversy there but there is none in matters of health, where all reach the same level of interest, employer and employed alike and where there is no room for controversy."13

Such a policy was clearly unworkable and it did not convince the Confederation of Employers Organisations to support its work despite ten or more years of attempts to do so. The IHES must nevertheless have organised a programme broadly within these basic guidelines because it succeeded in maintaining the support of peers, the prime minister and ministers of health, the monarchy, and some large employers throughout its history.

The IHES adopted several quite radical educational methods including worker control over the curriculum within certain limits. Talks were requested by workers and organised by those workers on a wide range of occupational and general health topics. The society's annual reports show that in the first years the IHES organised over 150 talks a year. ${ }^{14}$ By 1927 there were 285 talks a year, in 1928 398, and 1934 388. In the late 1920 s and 1930s the IHES arranged an average of just under 400 talks a year. In 1929 some 14911 workers attended its meetings.

The audiences for these talks consisted mainly but not exclusively of male trade unionists. After 1930 policy changed and efforts were made to reach "women working in the mills, workshops and factories" and "male workers unattached to trade unions." In 1928 the London area of the IHES had already established a women's committee to give talks to women on health and work.

Subjects of the talks ranged from bakers dermatitis to painters colic, garage workers carbon monoxide headaches to woodworkers skin trouble, mule spinners cancer to industrial rheumatism, and miners "beat" conditions to fume fever in metal casting. Along the way the hazards of office workers, asylum staff, the unemployed, confectioners, laundry workers, and farm workers were also covered.
In addition to talks, the IHES produced leaflets on eye trouble in industry, rheumatism among steel workers, mule spinners cancer, dust phthisis or $\overrightarrow{0}$ silicosis, milk and lead workers. It instigated $\frac{0}{0}$ inquiries at union request, into working conditions in $\overline{\bar{c}}$ the iron and steel industry (Confederation of British $\vec{\varnothing}$ Industries Archive MS 200 b/3/2/C693, Modern Records Centre, University of Warwick). For the क mining unions, the society organised exhibitions on $\overrightarrow{0}$ occupational health in the late 1920 s that attracted $\vec{\overrightarrow{ }}$ between 500 and 1200 people per exhibition. Films $\vec{\omega}$ from health education bodies and the Ministry of Health were also shown by the IHES (CBI archive).

\section{Responses to the IHES work GOVERNMENT}

initiatives and

The government supported voluntary initiatives and $\mathscr{\circ}$ a tripartite approach to a whole range of health and $\mathrm{O}$ welfare issues in the 1920s and 1930s. There was therefore sympathy but no cash for the work of IHES. Ramsay MacDonald, as prime minister, was an honorary vice-president of the society and appeared as guest speaker at its annual general $\vec{\emptyset}$ meetings. Ministers of health attended IHES public. meetings and spoke in its favour. The chief medical $\square$ officer of the Ministry of Health praised the Society's work in 1927 and observed that health and safety education was best done by the voluntary sector and not by the state.

When the IHES wound up its talks service in 1940, and donated its funds to the BMA for occupational health education lectures, there appeared to be a view that the state would now deal with both occupational health and related educational issues, thereby making the IHES redundant. There were hopes that a $\mathbb{D}$ national health service would cater for occupational health and that factory conditions would improve and greatly reduce the occupational health hazards workers faced up to 1939 . This was partly supported in 1940 by the Factories Order that gave factory inspectors power to ask employers to appoint full time or part time medical officers to their works. ${ }^{15}$ D Many of these hopes remained unfulfilled, especially the creation of a national occupational health service $N$ and worker participation in occupational health committees in the workplace.

\section{TUC AND TRADE UNIONS}

From its inception the IHES had the active support $\varphi$ of the Scottish trade unions, especially the miners. $\mathbb{D}$ Later support, both financial and organisational, $\stackrel{+}{-}$ came from the TUC and affiliated trade unions. In a 0 sense the non-political and non-controversial stance of the IHES was in line with TUC policy at the time $\stackrel{\mathbb{\square}}{\mathbb{9}}$ which adopted a pragmatic policy of calling for the $\stackrel{\mathbb{Q}}{\Omega}$ "adequate maintenance and compensation for indus- $\overline{-}$ trial disease and accident" rather than a radical programme of removing occupational hazards. The 
tensions between those in the trade unions committed to social amelioration and those committed to the TUC policy document in 1924 on the "Waste of Capitalism"- -with its calls for socialism and worker control of production and hence worker control over hazards-must have been great but remain undocumented in the IHES papers.

Official trade union support for the IHES programme came from unions in plumbing, electricity, building, iron and steel, railways (offices and track), mining, brass, bakeries, boot and shoe industries, post offices, shops, distribution, chemicals and drugs, woodworking, cotton industries, administration, printing, furniture, carpet weaving, and painting. Trades councils across England, Wales, and Scotland subscribed to the IHES Miners unions in Monmouth, Durham, Northumberland, General Municipal Boilermakers and Allied Trades, central Scotland, Lothian and Lanarkshire and the Transport and General Workers' Union and proved to be the strongest financial backers of the society.

\section{EMPLOYERS}

The original IHES campaigns emphasised the economic damage done to employers by occupational ill health. It is therefore no surprise to find that individual employers, especially in Scotland and the north, supported the work of the IHES by cash donations and subscriptions. Brewers, printers, engineering companies, and textile companies were strongly represented.

Lord Melchett, from the chemical industry, was an early president of the society but none of the major employers federations was willing to follow his lead. The small National Union of Manufacturers recognised the society but other trade organisations saw accidents and not diseases as the major health and safety problems and supported the National Safety First Movement which espoused the careless worker philosophy rather than the more radical IHES.

The Council of British Employers' Organisations and the Federation of British Industry viewed the trade union, labour club, trades council, and the Cooperative Women's Guild links of the IHES as far too threatening a political influence to countenance its recognition (CBI archive).

\section{MEDICAL WORKERS}

The foundations and development of the IHES rested on the active participation and support of doctors throughout the country who were willing to spend time and offer their skills free to the society. The health talks to trade unionists outside their workplaces in clubs and pubs and halls was the principal aim and the central activity of the society. The participation of leading figures in medicine was the first vital step in securing wider support among doctors for the IHES. Mackenzie achieved this objective, although the responses of the medical profession to IHES varied over the life of the society. Some were unequivocally in favour of its work, others waxed and waned, and yet others viewed it with suspicion if not hostility.

Eminent Edwardian figures such as the King's physician, Lord Horder, the Cambridge professor of physic, Sir Humphrey Rolleston, and Professors Sir Thomas Oliver, E L Collis, J Glaister, and Sir Robert Philip all supported the IHES quite actively: most for more than a decade. Collis and Oliver prepared materials and pamphlets for circulation by the society to workers.

The Society of Medical Officers of Health, was officially represented on the area councils of IHES and individual medical officers of health played a major part in running the IHES and speaking at its meetings. In 1927, 192 doctors sat on the five area councils of the society and these included no fewer than 59 medical officers of health. Local doctors also gave their talks free to the IHES until late in the 1930s, when some doctors apparently started charging a guinea for speaking at IHES meetings, and some regularly paid the guinea annual subscription to the society.

Opinion differed about the work of the IHES and the direction in which it should go. Lord Horder, probably to the astonishment of his colleagues working in occupational medicine, felt able to declare in 1932 that major industrial accidents and diseases "had been reduced to very small proportions, if not eliminated, and the grosser industrial diseases and disabilities were no longer the main subject upon which the doctors talked to workers. The [IHES] talks now much more often concerned personal hygiene, minor ailments, ventilation, and food values." Indeed by 1934 Horder wanted to see the IHES linked more closely to the work of the Eugenics Society-with its aim "to improve human racial qualities by rational selection"-in the future as its occupational health work, he believed, was declining. What connection the Eugenics Society had with occupational health was not explained by Horder. ${ }^{17}$ His view of the decline in occupational hazards is not supported by IHES annual reports which continued to list talks to workers on a wide range of occupational diseases in a wide range of industries.

Sir Thomas Oliver's views were rather different. At an IHES meeting in Leeds in 1929 he noted: "New industries are always developing and new industries mean new disease. We must always be on the look out for what new ailments new industries may bring." Oliver was particularly concerned about the need for safe workplace policies in the IHES approach and emphasised improved ventilation as the solution to dust and fumes problems. ${ }^{18}$ As late as 1934 Oliver remarked that "Again and again workers had said to him that if they had only known of the 
dangers to which they had been exposed they would have taken greater precautions." 19 Sir Thomas Legge, in meetings with the IHES, also emphasised that "the responsibility for maintaining good conditions rested on the employers." 20

\section{OTHER ORGANISATIONS}

The IHES had links with a wide range of bodies interested in welfare at work and industrial efficiency and productivity including the National Institute of Industrial Psychology, the Industrial Health Research Board, the Industrial Welfare Workers Association, and the Royal Sanitary Institute. When the Society of Medical Officers of Health appointed a Central Council for Health Education in 1927, Mackenzie hoped the council would make use of the IHES through local authorities in renewed efforts to reach workers. In practice, the council appeared to be competing with the IHES as did the National Safety First Association with its rival philosophy of "careless workers and the need for safe workers."

\section{Current position on occupational health education}

No organisation such as the IHES exists today. The IHES voluntary approach-geared in theory to tripartism, the development of consensus, and the control of conflict-is probably mirrored closest by the Industrial Society's health and safety work. Groups such as the British Society for Social Responsibility in Science, Hazards, the Labour Research Department (a trade union research group not affiliated to the Labour Party despite its name) probably come closer to the practice of the IHES but without the reliance on doctors.

Doctors have vanished almost completely from voluntary involvement in worker education on occupational health. This may be explained by the establishment of the Employment Medical Advisory Service and the passage of the 1974 Health and Safety at Work Act, the expansion in the number of occupational physicians since the $1930 \mathrm{~s}$, or the reluctance of doctors to address issues that might cause controversy with local employers and mean that they would be associated with trade unions on the shopfloor. Whatever the reasons, they are beyond the scope of this paper.

The occupational health projects in Sheffield, Bradford, and London are also concerned about improving the flow of information on occupational health to workers but reject the non-political, noncontroversial, neutral scientific stance of the IHES philosophy geared to safe worker rather than safe workplace philosophies.

Within the Health and Safety Executive and Health and Safety Commission and indeed local authorities there are much greater resources and staff available for occupational health work than in the 1920 s but little is devoted to formal occupationat. health education and almost none to workes? occupational health education.

Although in absolute terms the United Kingdon position on occupational health in 1990 is mucfs better than that in 1922 or 1944 , nevertheless therg are still major deficiencies. The toll fromy occupational disease is still large and few workers are fully informed about the hazards they face in the workplace. Inadequate resources and staff are devoted to occupational health regulation by centrap and local government (through EMAS and the Health and Safety Executive, environmental health officers, etc), by employers, by the NHS, and indeect by the trade unions. The medical model dominate occupational health practice. There is still ng national state occupational health service? Occupational health and medicine has low status in academic and medical circles. Occupational health standards, controls, and enforcement have deteriorated considerably since the early 1970s an $\Phi$ appear to be rapidly getting even worse.

The tensions that existed for the IHES still exis? for those working in occupational health now. The role of employers in removing or controlling healtp hazards is at best ambiguous. There may be conflicts and constraints for health educators wishing to raise hazard removal issues with employers rather thar victim blaming policies.

\section{Assessment and conclusion}

IHES fullfilled most of its original aims:

It reached a large number of workers with basic health and safety information through talks, the distribution of leaflets, and exhibitions.

It cooperated with and involved leading medica figures and local doctors, government members other politicians, and some employers in a majos programme of occupational health education. The campaigns acquired new knowledge on the exten 9 and nature of occupational disease and helped educate the doctors as well as the workers on the subject.

It produced and sustained an important occu pational health campaign over a decade or more if popular and serious newspapers and medical and scientific journals.

How exactly these successes actually removed hazards, influenced workers, and reduced occu pational ill health cannot be assessed accurately osp present.

The Society did not succeed:

in involving employers in its work to any greas extent. If it had done so it seems that it would hav $\mathbb{\Phi}$ alienated many of the workers who attended it talks and it might have failed to produce such an effective and generally accurate informatio 
service on hazards and how to remove them; in identifying the economic and political causes of occupational ill health, at least not overtly at a national level, although caution in this respect may have ensured the support and financial help of its "establishment" patrons in the medical and political fields;

in directing its resources always at the main issues. For instance at an early stage it began a programme of health education work on teeth and dietsworthy causes but somewhat peripheral to its original aims and certainly much less contentious. The IHES was a unique organisation that did not fit exactly into either the mould of consensus building or radical organisations of the 1920 s and 1930s. It did reach large numbers of workers on the shopfloor, primarily trade unionists, with necessary basic information about occupational hazards. The IHES also faced all the problems about voluntarism, self regulation, deregulation, scientific neutrality, consensus building, conflict resolution, and victim blaming that health and safety workers faced in the 1980s.

1 Waldron HA. Academic occupational health under threat. $\mathrm{Br}$ Med J 1989;299:74.

2 Harrington $M$, Philipp $R$, Seaton A. Undergraduate occupational health teaching in British medical schools. Journal of the Royal College of Physicians 1989;23:24-7.
3 Snashall D. Undergraduate teaching of occupational health. $\bar{B} r \bar{J}$ Ind Med 1989;46:433-4.

4 British Health and Safety Society. Educational and training in health and safety: the neglected imperative. Aston: BHSS, 1989.

5 Watterson A. Occupational health and illness: the politics of hazards education. In: Rodmell S, Watt A, eds. The politics of health education. London: Routledge, Kegan Paul, 1986: 76-99.

6 Webb A, Schilling R. Health at work: a report on health promotion in the workplace. (HEA res rep No 22.) London: Health Education Authority, 1988.

7 Harvey S. Just an occupational hazard? In: Policies for health at work. London: Kings Fund Institute, 1988.

8 Oliver T. The health of workers. London: Faber and Faber, 1925:186.

9 Legge T. Industrial maladies. London: Oxford University Press, 1934:3.

10 Smiley JA. Some aspects of the early evolution of the appointed factory doctor service. $\mathrm{Br} J$ Ind Med 1971;28:315-22.

11 Djang TK. Factory legislation in Great Britain. London: Allen and Unwin, 1942:110.

12 Editorial. Educational partnerships in industrial health. Lancet 1929;ii:989-90.

13 Mackenzie J. Annual report of the IHES. London: Industrial Health Education Society, 1927:7.

14 Industrial Health Education Society. Annual reports 1926 to 1934. London: IHES.

15 News item. Br Med J 1940;ii:62.

16 News item. Br Med J 1933;i:336.

17 News item. Br Med J 1934;i:441.

18 Manchester Guardian 19th October 1929.

19 News item. Br Med J 1934;i:442.

20 Industrial Review. III. No 4. April 1929.

Accepted 30 October 1989
All manuscripts submitted to the $B r J$ Ind Med should conform to the uniform requirements for manuscripts submitted to biomedical journals (known as the Vancouver style)

The $\mathrm{Br} J$ Ind Med, together with many other international biomedical journals, has agreed to accept articles prepared in accordance with the Vancouver style. The style (described in full in $\mathrm{Br}$ Med J, 24 February 1979, p 532) is intended to standardise requirements for authors.

References should be numbered consecutively in the order in which they are first mentioned in the text by Arabic numerals above the line on each occasion the reference is cited (Manson ${ }^{1}$ confirmed other reports ${ }^{2-5} \ldots$.). In future references to papers submitted to the $\mathrm{Br} J$ Ind Med should include: the names of all authors if there are six or less or, if there are more, the first three followed by et al; the title of journal articles or book chapters; the titles of journals abbreviated according to the style of Index Medicus; and the first and final page numbers of the article or chapter.

Examples of common forms of references are:

1 International Steering Committee of Medical Editors. Uniform requirements for manuscripts submitted to biomedical journals. Br Med J 1979:1:532-5.

2 Soter NA. Wasserman SI, Austen KF. Cold urticaria: release into the circulation of histamine and eosino-phil chemotactic factor of anaphylaxis during cold challenge. $N$ Engl $J$ Med 1976;294:687-90.

3 Weinstein L, Swartz MN. Pathogenic properties of invading micro-organisms. In: Sodeman WA Jr, Sodeman WA, eds. Pathologic physiology: mechanisms of disease. Philadelphia: W B Saunders, 1974:457-72. 